J. Amer. Soc. Hort. ScI. 115(4):672-674. 1990.

\title{
Inheritance of Resistance to Goss's Wilt in Sweet Corn
}

\author{
C.L. Treat and W.F. Tracy \\ Department of Agronomy, University of Wisconsin-Madison, Madison, WI 53706 \\ Additional index words. Zea mays, Corynebacterium michiganense ssp. nebraskense, diallel, general combining ability, \\ specific combining ability
}

\begin{abstract}
Goss's wilt is a bacterial wilt and blight that may cause yield losses up to $50 \%$ or greater in sweet corn. Ten hybrids from a diallel cross of five sweet corn (Zea mays L.) inbreds were analyzed for resistance to Goss's wilt (Corynebacterium michiganense ssp. nebraskense Schuster, Hoff, Mandel, and Lazar) in 1987 and 1988. The inbreds used to make the diallel were widely used historically and were chosen on the basis of adaptation and relative maturity. Three hybrids were resistant and seven intermediate, while the field corn controls were extremely susceptible. General combining ability (GCA) and specific combining ability (SCA) sums of squares accounted for $94 \%$ and $6 \%$ of the variation among crosses, respectively. GCA was highly significant $(\mathbf{P} \leq 0.01)$, while SCA was nonsignificant. Year differences were nonsignificant, but date of rating and hybrid $\times$ year interaction effects were significant $(P$ 0.05). Resistance to Goss's wilt is available in sweet corn, and recurrent selection should be effective if improvement in resistance is desired.
\end{abstract}

Goss's bacterial wilt and blight of corn may attack plants at any stage of development and reduce yields by $50 \%$ or more (Wysong and Doupnik, 1984). The wilt has been referred to as a "warm weather disease" because the symptoms do not appear until mid- to late season, when temperatures are high (Smidt and Vidaver, 1986). Typical symptoms are dark green to black, discontinuous, water-soaked spots (freckles) along the margins and/or ends of developing lesions (Schuster, 1975; Schuster et al., 1972; Shurtleff, 1980; Wysong and Doupnik, 1984; Wysong et al., 1981). Light greenish-yellow or reddish stripes with wavy, irregular margins occur along the leaf veins. An orange bacterial exudate may appear on the surface of diseased tissue. When dry and examined in the sunlight, the exudate glistens. As the lesions coalesce, the symptoms resemble leaf scorching due to drought. A dry or water-soaked brown root and stalk rot, along with wilting and stunting, have been found in systemically infected plants.

Common names include Goss's wilt, Goss's bacterial wilt and blight of corn, leaf freckles and wilt, Nebraska leaf freckles and wilt, and bacterial leaf blight and wilt (Schuster, 1975; Wysong et al., 1981). The first sighting of Goss's wilt occurred in mid-August of 1969 on a popular field corn hybrid near Lexington, Neb. (Wysong et al., 1973). By 1975, the disease also was reported in Iowa, Kansas, South Dakota, and Colorado (Wysong et al., 1981); it was first seen in Illinois in 1980 and in Wisconsin in 1981 (Wysong et al., 1981).

When continuous corn or conservation tillage methods are used, resistant hybrids are the best means of control. A recent

Received for publication 3 Apr. 1989. Contribution from the Dept. of Agronomy, Univ. of Wisconsin, Madison. Research supported by Wisconsin Agr. Expt. Sta., Madison, and Midwest Food Processors Association. The cost of publishing this paper was defrayed in part by the payment of page charges. Under postal regulations, this paper therefore must be hereby marked advertisement solely to indicate this fact. study showed high correlations for the reactions of sweet corn hybrids to northern corn leaf blight [Exerohilum turcicum (Pass.) Leonard and Suggs] races 1 and 2, Stewart's wilt [Erwinia stewartii (E.F. Smith) Dye], and Goss's wilt (Pataky, 1985). Reaction to Stewart's wilt is highly heritable, predominantly additive, and governed by few genes (Blanco et al., 1979; Forgey et al., 1982). Resistance to northern corn leaf blight is both quantitative and qualitative. A lesion-number form of resistance is polygenically inherited (Hughes and Hooker, 1971). A chloroticlesion type of resistance is conditioned by a single dominant gene (Hooker, 1963).

Gardner and Schuster (1973) reported that reaction to Goss's bacterial wilt and blight of corn was probably controlled by more than one major gene. Martin et al, (1975) found that the inheritance of susceptibility and resistance appeared to be quantitative, with partial dominance for susceptibility. Our objective was to obtain information on the inheritance of resistance to Goss's wilt in sweet corn by the use of diallel mating.

\section{Materials and Methods}

A five-line half diallel, Griffing's Method 4 (1956), was used. The inbred lines used to produce the diallel were: C23, C68, P39M94, Ia5125a, and Ia453. These lines were chosen because of their historical importance and on the basis of their adaptation and relative maturity. Reaction to the disease was not considered in choosing the lines. An $\mathrm{F}_{1}$ half diallel without parents was grown at the Arlington Experimental Station, Arlington, Wis., in 1987 on a Piano silt loam (fine-silty, mixed, mesic, Typic Argiudoll). In 1988, the half diallel, including the parents, was grown at the West Madison Experimental Station, Madison, Wis., which also has Piano silt loam soil. A susceptible dent corn control was included each year. In 1987, a resistant dent control was also included. A randomized complete-block design with three replicates of single-row plots was used. Plots were 
overplanted and later thinned to 20 plants per plot to provide a population of 49,900 plants/ha. All plants were inoculated at the five-leaf stage with $\approx 2 \times 10^{8}$ cells $/ \mathrm{ml}$ of Goss's wilt bacteria via the pin-prick method of Blanco et al. (1977). The inoculum for 1987 was isolated from leaves that contained natural infection and were collected in 1986 in Wisconsin. The bacterium was isolated and grown on a selective medium for Goss's wilt (Gross and Vidaver, 1979). In 1988 the inoculum was a composite obtained from the Plant Pathology Dept. at the Univ. of Nebraska, Lincoln. Visual ratings were taken twice on a row basis: at the fresh-market stage $(\approx 20$ days after midsilking) and 2 weeks later. Ratings were on a scale where $1=$ nearly dead and $9=$ absence of symptoms. Within this scale, 1,2 , and 3 were considered susceptible, 4, 5, and 6 intermediate, and 7, 8, and 9 resistant. An analysis of variance was used to compare mean plot ratings. Date and entry effects were considered fixed, while year and replication effects were considered random.

\section{Results and Discussion}

Differences $(P \leq 0.01)$ in mean response to Goss's wilt were observed among hybrids. Years were nonsignificant, while date of rating and hybrid $\times$ year interaction effects were significant $(P \leq 0.05)$. The hybrid $\times$ year interaction should be addressed in planning a selection program. The severity of the disease increased from the first (mean 6.7) to the second rating date (mean 6.2). Two hybrids, C23 × P39M94 and C68 $\times$ Ia5125a, were in the resistant group in 1987 but in the intermediate group in 1988, while hybrid C23 $\times \mathrm{Ia} 453$ was in the intermediate group in 1987 and in the resistant group in 1988. This significant interaction suggests that testing over multiple environments should be used when breeding for increased resistance to Goss's wilt. GCA accounted for $94 \%$ of the variation among hybrids and was highly significant $(P \leq 0.01)$, while SCA accounted for only $6 \%$ of the variation among hybrids and was nonsignificant. Additive gene action was more important than dominance in resistance for Goss's wilt in this set of hybrids. Treat et al. (1990) reported that in two diallel experiments made with dent corn, GCA sums of squares accounted for $98 \%$ and $91 \%$ of the variation among crosses, while SCA accounted for $2 \%$ and $9 \%$.

The mean disease ratings for hybrids ranged from 8.2 to 4.3 (Table 1). Hybrids P39M94 × C23, Ia5125a × P39M94, and

Table 1. Mean Goss's wilt ratings ${ }^{z}$ for hybrids (above diagonal), for inbreds (diagonal), and general combining ability (GCA) effects (right columin) of a five-line sweet corn diallel.

\begin{tabular}{lcccccc}
\hline \hline & C23 & Ia5125a & P39M94 & C68 & Ia453 & GCA \\
\hline C23 & $8.2^{\mathrm{y}}$ & $8.2^{\mathrm{x}}$ & 7.0 & 6.3 & 6.8 & $0.80^{\mathrm{w}}$ \\
Ia5125a & & 7.0 & 8.0 & 6.8 & 6.3 & 1.13 \\
P39M94 & & 6.8 & 5.5 & 5.5 & 0.08 \\
C68 & & & 5.5 & 4.3 & -1.01 \\
Ia453 & & & & 5.0 & -1.01 \\
Controls & & & & \\
$\quad$ ND250 x A634Ht $=1.8^{\mathrm{v}}$ & & & & \\
Mo17Ht x A638 $=8.3$ & & & & \\
A632Ht = 2.0 $\mathrm{y}$ & & & & \\
LSD (0.05) for inbreds $=0.9$ & & & & \\
LSD (0.05) for hybrids $=0.8$ & & & & \\
\hline
\end{tabular}

$\mathrm{z}_{1}=$ susceptible, $9=$ resistant.

y Mean of two rating dates and three replications grown in 1988 .

Mean of 2 years, two rating dates, and three replications.

${ }^{w_{S E}}\left(g_{i}\right)=0.14$, SE $\left(g_{i}-g_{j}\right)=0.22(i \neq j)$.

vMean of two rating dates and three replications grown in 1987.
Ia5125a $\times \mathrm{C} 23$ ranged from 7.0 to 8.2 , while $\mathrm{Ia} 453 \times \mathrm{C} 68$, Ia453 × P39M94, C68 × P39M94, C68 × C23, Ia453 × Ia5125a, Ia453 $\times$ C23, and Ia5125a $\times$ C68 ranged from 4.3 to 6.8 . No hybrids were susceptible. The dent corn controls ND250 $\times$ A634Ht and $\mathrm{Mo} 17 \mathrm{Ht} \times \mathrm{A} 638$ were rated 1.8 and 8.3 , respectively, in 1987, while the dent corn inbred control A632Ht was rated 2.0 in 1988. The ratings of the susceptible controls indicate that the pathogen was virulent and that inoculation was effective.

The parental inbred lines C23 and Ia5125a were resistant, while inbreds P39M94, C68, and Ia453 were intermediate (Table 1). No inbreds were susceptible. Inbreds C23, P39M94, and Ia5125a had positive GCA effects (Table 1), and C68 and Ia453 had negative GCA effects. A higher positive GCA indicates a higher level of resistance.

This sweet corn germplasm has adequate resistance to Goss's wilt, and resistance is controlled primarily by additive gene action. The importance of additive gene action agrees with studies on dent corn on Goss's wilt. Treat et al. (1990) reported that additive gene action was more important than dominance for resistance to Goss's wilt in field corn. Martin et al. (1975) concluded that breeding techniques concentrating on additive gene effects should be effective in breeding for resistance to Goss's wilt. Pataky (1985) found a high correlation for the reaction of sweet corn to Goss's wilt and Stewart's wilt. According to Blanco et al. (1979), the reaction to Stewart's wilt is largely additive. Since additive variance is the chief cause of resemblance between relatives, the importance of additive gene action over dominance in this material indicates that recurrent selection should be effective in increasing resistance.

\section{Literature Cited}

Blanco, M.H., M.G. Johnson, T.R. Colbert, and M.S. Zuber. 1977. An inoculation technique for Stewart's wilt disease of corn. Plant Dis. Rptr. 61:413-416.

Blanco, M.H., M.S. Zuber, J.R. Wallin, D.V. Loonan, and G.F. Krause. 1979. Host resistance to Stewart's disease in maize. Phytopathology 69:849-853.

Forgey, W.M., M.H. Blanco, L.L. Darrah, and M.S. Zuber. 1982. Prediction of Stewart's wilt disease in single and three-way crosses of maize. Plant Dis. 66:1159-1162.

Gardner, C.O. and M.L. Schuster. 1973. Genetic studies of susceptibility to bacterial leaf freckles and wilt, Corynebacterium nebruskense. Maize Genet. Coop. Nwsl. 47:155-157.

Griffing, B. 1956. Concept of general and specific combining ability in relation to diallel crossing systems. Austral. J. Biol. Sci. 9:463493.

Gross, D.C. and A.K. Vidaver. 1979. A selective medium for isolation of Corynebacterium nebraskense from soil and plant parts. Phytopathology 69:82-87.

Hooker, A.L. 1963. Monogenic resistance in Zea mays L. to Helminthosporium turcicum. Crop Sci. 3:381-383.

Hughes, G.R. and A.L. Hooker. 1971. Gene action conditioning resistance to northern leaf blight in maize. Crop Sci. 11: 180-184.

Martin, P.R., C.O. Gardner, A.G. Calub, and M.L. Schuster. 1975. Inheritance of susceptibility and tolerance to leaf freckles and wilt (Corynebacterium nebraskense) of corn. Maize Genet. Coop. Newsl. 49:137-138.

Pataky, J.K. 1985. Relationships among reactions of sweet corn hybrids to Goss's wilt, Stewart's bacterial wilt, and northern corn leaf blight. Plant Dis. 69:845-848.

Schuster, M.L. 1975. Leaf freckles and wilt of corn incited by Corynebacterium nebraskense Schuster, Hoff, Mandel, Lazar. 1972. Neb. Agr. Expt. Sta. Res. Bul. 270.

Schuster, M.L., B. Hoff, M. Mandel, and E.I. Lazar. 1972. Leaf freckles and wilt, a new corn disease. Proc. 27th Annu. Corn and Sorghum Res. Conf. Chicago, Ill., Dec. 12-14. 27:176-191. 
Shurtleff, M.C. (ed.). 1980. Goss's bacterial wilt and blight. Compendium of corn diseases. 2nd ed. Amer. Phytopath. Soc. St. Paul, Minn. p. 7-8.

Smidt, M. and A.K. Vidaver. 1986. Population dynamics of Clavibactor michiganense subsp. nebraskense in field-grown dent corn and popcorn. Plant Dis. 70:1031-1036.

Treat, C.L., W.F. Tracy, P.N. Drolsom, and J.G. Coors. 1990. The inheritance of resistance to Goss's wilt in maize. Crop Sci. (In press.)

Wysong, D.S. and B. Doupnik, Jr. 1984. Goss's bacterial wilt and blight of corn. Nebguide. Coop. Ext. Serv. IANR Univ. Neb. Lincoln. G84-691.

Wysong, D.S., B. Doupnik, Jr., and L. Lane. 1981. Goss's wilt and corn lethal necrosis - can they become a major problem? Proc. 36th Annu. Corn and Sorghum Res. Conf. Chicago, Ill., Dec. 9-11. 36:104-152.

Wysong, D.S., A.K. Vidaver, H. Stevens, and P. Stenberg. 1973. Occurrence and spread of an undescribed species of Corynebacterium pathogenic on corn in the western corn belt. Plant Dis. Rptr. 57:291-294. 